\title{
Theoretical and Practical Research on the Transformation and Development of Independent Colleges
}

\author{
Siyou Zhang ${ }^{1, a}$, Lianggang Wang $^{1}$ and Shuting $\mathrm{Xia}^{1}$ \\ ${ }^{1}$ City College, Wuhan University of Science and Technology, Wuhan, Hubei Province, China \\ a1585143263@qq.com
}

Keywords: independent college, applied technology, transformation and development.

\begin{abstract}
In order to implement the strategy released by the State Council executive meeting of "To guide the transformation of a number of undergraduate institutions and make them technology-based universities". This paper explores the opportunities and challenges faced by local independent colleges. By learning from practical experience of foreign applied technology universities, this paper clarifies the practical requirements and objectives of the independent colleges' transformation. In terms of the practice of the author's working place and the combination of production and teaching, this study explores the approaches of the transformation of local undergraduate colleges, as well as the construction of applied technology universities with Chinese features.
\end{abstract}

\section{Introduction}

Review of independent colleges. In 2003, it was firstly officially put up by the Ministry of Education that "independent colleges specially refer to the secondary colleges of the undergraduate level, which are set up by regular undergraduate institutions according to the new mechanism and mode".[1] As independent colleges develop, in order to regulate the notion and nature of them, the No.26 law , which was laid down by the Ministry of Education of the People's Republic of China and carried out since April in 2008, reflected that "independent colleges refer to the institutions of higher education, which carry out bachelor degree education and are set up by the cooperation of regular undergraduate institutions carrying out the education of bachelor degree or above and individuals or social organizations except state institutions with the non-state fiscal funds".[2]

Independent colleges as the important achievement of the research and innovation of the higher education school-running system have made positive contributions to developing non-governmental education undertakings and promoting the popularization of higher education. Throughout over ten years' development, Independent colleges have become one of the important powers of the higher education in our country.

According to the statistical data released by the Ministry of Education, by 2013, there are 303 independent colleges in total in our country. And there are 2,780,000 students in independent colleges, among which are 2,620,000 undergraduates.[3] As the level of popularization of higher education improves incessantly, the competitions among colleges and universities are more and more fierce. Facing the new background, new chances and new challenges, independent colleges must have their own way of development, which should conform to their actual condition.

The opportunity and challenges faced by independent colleges. At present, the high-level undergraduate institutions all try to develop towards "Research University", and highly professional industry colleges gradually develop into comprehensive universities. At the same time, independent colleges' position as "practical" and "instructional" can fill up the gap and has large development space. Therefore, only by seizing the opportunity, finding the exact position, and researching new mode of running school can independent colleges go ahead stably on the way of transformation and development.

Independent colleges enroll the third undergraduate batch students. Therefore, the quality of student resources is comparatively worse compared with that of regular undergraduate institutions. The theoretical level of independent colleges' graduates is not the match of that of graduates in research universities, and the practical level of them is behind that of graduates in technical colleges. 
Because of this, graduates of independent colleges meet many obstacles in the job market, and the social recognition about them is low. How to exploit the space for existence and development in the aspect of student resources and job market is the major challenge faced by independent colleges, and the transformation development is imminent.

\section{Practical Experience of Applied Technique-oriented Universities Abroad}

At the beginning of 2004, it is put up at the committee of the state council that "We should open up a rising passage from secondary vocational school, junior college, undergraduate to postgraduate, and lead a batch of regular undergraduate institutions to transform into applied technique-oriented universities". There have been many experience and methods upon this project abroad. Therefore, referring to the successful cases abroad is beneficial for independent colleges to research the way of transformation.

The framework of occupational qualification is popular abroad. Its advantages are building the system of vocational certificate of education and forming the certificate system parallel to and equivalent to the academic certificate system, which largely expand the space for the rising of vocational education level. Australia is one of the countries which exploit the framework of occupational qualification earliest. The 15 types of qualification set by it include 10 vocational qualification certificates and 5 academic certificates. And each type depicts concretely in the three aspects of knowledge, skill and application and forms complete system. The UK's "framework of qualification and credit", which consists of credit system and qualification blocking, sets 9 qualification levels including 8 qualification levels and 1 entry level, which builds a complete system of vocational certificates from the lowest level to the highest.

In the aspect of colleges and universities serving the local economic development, the experience of many universities abroad also deserves learning. For example, the US sets up "Palo alto center of science and industry", which is centered with "Stanford university", and sets "University of California" and "the California institute of technology" as main force. "University of Wisconsin" builds good relationship with the government in the aspect of serving local economic development. It can appoint experts to serve the state government and they can even deliver professors to countryside, factories, and shops to do the guidance if needed by the society. Meanwhile, the university also invites experts of the society to participate in the teaching and scientific research of the school, so as to link the society tightly and cultivate the students into excellent talents for serving the society.

The development of higher education abroad reflects that the development of economy contributes to applied universities, and the development of applied universities lays the foundation of the development of economy. Because of that, the employment of graduates of colleges and universities is guaranteed, and the national competitiveness is improved constantly, which forms the win-win outcome of the development of both higher education institutions and social economy and brings virtuous circle.

\section{Strategies and Methods of the Transformation and Development of Independent Colleges in China}

Reasons for the transformation of independent colleges. Practice teaching has always been the weakness of the higher education of our country. The development of local economic development needs not only research talents but also a lot of skilled talents.

Our country has come into the stage of mass higher education, so we need to accelerate the application and accumulation of advanced technology. It is urgent to cultivate highly-competent talents who can serve to the first-line production. Independent colleges also must be oriented with the construction of local economy and comply with the need of the development of local economy. By the way of transformation, independent colleges need to cultivate the technical personnel who are different from the talents of the "research universities" and "comprehensive universities" but can gain a firm foothold at the first line of production, management and service. 
Firstly, in the process of transformation, independent colleges value the adaptability of the major in the market, get to know the condition of the market, and set the corresponding courses which are oriented with market requirements, so as to make plans for the cultivation of talents with vocational ability. Meanwhile, the schools can build positive links with the enterprises to accelerate the teaching reform, which can reflect the social needs and corporation production timely and adequately.

Secondly, independent colleges will strengthen the construction of outside campus practical skills training base. Only by practicing and experiencing personally can students find out the problems and the shortcomings of their own during the practice of production, management and service. And only by that can teachers make up for the deficiency pointedly in the class and improve the professional quality and practice ability so as to improve the employment competitiveness of students.

Thirdly, teachers can have the chance to go to the enterprises and get to know the production to avoid the appearance of the phenomenon that teachers can't solve the problems faced in the practical production. In this way, teachers can explain the profound theories in simple terms to introduce the mixed knowledge of practical production and textbooks to the students, so as to make it receivable and understandable.

Fourthly, experienced technical talents and managers can be employed to teach at school and communicate and learn with the teachers. As a result, men of the enterprises can learn more key theoretical knowledge beneficial for the development of the technology, and teachers can get important reflection on the teaching methods and thinking.

All in all, transformation is good for both school and the market economy. Only the talents cultivated by the transformed schools can adapt to the development of market economy faster and better, and the market economy can make schools choose the right way of transformation in the process of the survival of the fittest. Thus is the objective and inevitable requirement of the history.

The transformation goals of independent colleges. In the process of the construction of applied colleges, it requires that independent colleges should combine adequately the social resources to develop the main subjects and majors, establish themselves in the application-oriented education, choose to cooperate with enterprises to run schools, and set up the platform for industry-college-research cooperation with enterprises, so as to make the teaching fuse with the industry demand, professional standard, and productive process of the enterprises and show their features which are different from the personnel training mode of the local regular undergraduate institutions and vocational colleges.

Approaches of the transformation of independent colleges. To realize the transformation of independent colleges, we can establish the complementary mechanism for teachers, strengthen major development, and build school-enterprise cooperation platform.

To establish complementary mechanism for school-enterprise leadership and teachers. The leaders in independent colleges can be skilled personnel serving in enterprises. Businessmen have the responsibility of building and reforming the independent colleges. Colleges also can hire technical personnel from enterprises for the faculty teachers, bringing the imitation of actual production into the classroom, so that students can more deeply experience the vivid corporate culture. At the same time, enterprises can also hire some faculty teachers to work in enterprises. This would help to enhance the teachers' practical ability of practicing, which achieves the exchange between enterprises and schools.

Take "City College of Wuhan University of Science and Technology" as an example (City College), the Department of Medicine hires retired medical experts and professors as full-time teachers from well-known hospitals, as well as the experts in care nursing within our province. In addition, the medical department still employs a number of well-known experts and professors as part-time teachers from Wuhan University and Wuhan University of Science. Young teachers are composed of graduate students with clinical experience. Department of Arts invites well-known artists and designers at home and abroad to give professional seminars every year. It also invites an international graphic design gurus and tenured professor who engages in Art and Design from Pennsylvania State University and regard him as the guest professor, which forms a good academic atmosphere. 
Based on their own professional features, colleges employ social hotshots. Therefore, they could involve in teaching, making information taught in the classroom and making it much closer to actual operations, which reflects the requirement of the society. By guiding students to analyze specific business cases, it can bring with practical reference and provide a blueprint for the students to apply their knowledge in the future. On the other hand, while the teachers work in the enterprises, they can not only brings back a lot of cutting-edge information with the times, but also adopt better teaching methods and make the best use of knowledge and practice according to different theoretical knowledge. In this way, they could make class much vivid and make the students experience the atmosphere of an enterprise role. Thus, they could have a clear understanding of current economy and themselves.

To strengthen major development and to promote educational reform. The majors in independent colleges show the necessity of applied talents who are in line with the needs of society. Thus, the key to cultivate applied-oriented talents is to enhance the major construction. Only by fostering professional personnel which meeting the needs of local economic development, can they seek their own development. Thereby, we should gather the resources from our society, government and enterprises for professional development services, which is a strong guarantee for an independent college during its transformation and make it application-oriented.

Independent colleges should conduct a comprehensive and detailed research for students to the demands and standards of job positions and determine the direction of personnel training. Through the analysis of job demands, they can design teaching modules and carry out teaching curriculum reform for the joint connection of curriculum system and enterprise.

Schools and enterprises could jointly establish a curriculum reform team, and complete the preparation of textbooks, instructional design, and teaching cases selection, which helps to achieve the link between students' ability and the enterprises' needs.

School of Medicine in City College, for example, adds a new major of pharmaceutical marketing in 2011, whose goal is to develop the "four understanding" application-oriented talents in market shortage, namely, "understanding medicine, pharmaceutics, marketing and management". With the increasing demands for diversity of talent in society, in 2012, it newly developed the major of applied chemistry which mainly teacher basic knowledge of theoretical chemistry, primary skills as well as relevant knowledge of engineering and technology. Thus, the students will receive better scientific thoughts of fundamental research thinking and scientific experimental training, so that they can be equipped with better scientific literacy and experimental skills to conduct applied studies, implement technology development and promote technology management. In order to highlight the practical skills training, in teaching it also uses an approach of "bringing in and going out", and create training programs for each professional curriculum of professional experiments and enterprise visits.

Based on the market analysis, setting up some majors in shortage of social needs can not only be conducive to student employment, but also be responsive to the society with important talents. After graduation, the students are more likely to engage in the professional jobs which are closely related to their major instead of starting all over again from scratch with their previous knowledge abandoned. While being in urgent demand of those people, our society should also put forward to higher requirements for our students. Independent colleges should continue to update the reform according to the market of teaching modules. Thus, we could cultivate more applied talents and they can quickly adapt to their jobs and do the best in their work.

To construct a platform and to create a favorable environment for school-enterprise cooperation. The training centers and collaborative R \& D platform could be established through school-enterprise cooperation. In this case, independent colleges can better train the employees; companies can better train the students. College teachers can undertake business-related R \& D projects. They could experience the industry connotation and play a catalytic role in prompting teaching methods and research project.

Academic leaders in Economics and Management Department in City College actively participated in the activity of "enterprise moving into the campus" and took part in the communication and discussion on hotspots of experimental teaching reform. Medicine department 
has also established internship relations with more than 30 provincial and municipal three-A hospitals in which students can access to the praise from hospital and gain job opportunities through their excellent performance and fundamental knowledge of professional theories, as well as practical ability. Department of Arts has constructed off-campus practice bases in multiple areas, such as Hongcun and Xidi in Anhui Province, Wuyuan in Jiangxi Province, Yunnan and other regions. It also establishes some professional practice and employment bases, for instance, Wuhan, Shanghai, Ningbo, Beijing, Guangzhou and so on. These bases provide practical teaching in a combined way of concentration and dispersion, which is proved to be excellent.

Meanwhile, City College also takes the unique advantage of cooperating operation with the "Wuhan Vocational College of Foreign Affairs" in order to share the same professional discipline internship training and establish long-term partnerships with relevant enterprises. It cultivates the undergraduates and vocational students with different levels and help them adapt the environment in enterprises, which is a firm foundation for them to enter into enterprises in the future.

\section{Conclusions}

In conclusion, the transformation of independent college is a necessity of social requirement and economic development. During the transformation, we could gather all kinds of resources of our society and the enterprises. In this case, we could train skilled personnel, strengthen school-enterprise cooperation, focus on major construction and promote educational reform. Therefore, we could contribute to the transformation of independent colleges and make them applied and high qualified.

\section{Acknowledgement}

This project is a key educational project supported by City College, Wuhan University of Science and Technology in 2014.

\section{References}

[1] Certain Opinions for Universities to Standardize and Strengthen the Construction of Independent Colleges with New Mechanism and Mode, 2003.Http : // www. Moe. Gov.cn /publicfiles /business /htmlfiles /moe /moe_637 /200408/ 1308.html

[2] Setup and Management of Independent Colleges, 2008. http : // www. Moe. Gov.cn /publicfiles /business / htmlfiles / moe / moe_1997 / 200804 / 31689.html

[3] Basic Situations of Private Education at All Levels, 2013. http : // www. Moe. Gov. Cn /publicfiles /business / htmlfiles / moe/s7567/2013 09/15 6892.html

[4] MA Luting \& FAN Wenyao. The Reality Basic and Policy Analysis of the Development of Independent Colleges, China Higher Education, 2005 (8).

[5]Approaches to Improve the Vocational Level at Abroad, 2014. http : // www. Tech.net. cn/ web /articleview .aspx ? Id = 2014052009440736 0\& cata_id =N041

[6] National Outline for Medium and Long Term Educational Reform and Development (2010-2020), 2010. http://www.china.com.cn/policy/txt/2010-03/01/content_19492625_2.htm

[7] AN Rongquan. Exploration into the Practice Mechanism of School - enterprise Community [N]. Guangming Daily, 2014-5-20 (14).

[8] The Focus of Cultivating Applied Talents [N]. China Education Daily, 2014-4-16 (1). 